УДК 37.091

DOI:

Борис Пантюхов, аспірант кафедри загальної педагогіки та дошкільної освіти Дрогобицького державного педагогічного університету імені Івана Франка

\title{
ЗМІСТ ПАТРІОТИЧНОГО ВИХОВАННЯ \\ КУРСАНТІВ ВИЩИХ ВІЙСЬКОВИХ НАВЧАЛЬНИХ ЗАКЛАДІВ
}

У статті на основі вивчення нормативно-правової бази узагальнено зміст патріотичного виховання курсантів вищих військових навчальних закладів (ВВНЗ). Проаналізовано основні завдання виховної роботи у (ВВН3), констатовано важливість патріотичного виховання курсантів. Подано визначення поняття “патріотичне виховання" майбутніх офічерів, доведено, щз його зміст охоплює систему знань, умінь, навичок, цінностей, норм і правил поведінки, оволодіння якими забезпечує формування суспільно активної особистості громадянина-патріота Украӥни, готового стати на захист Батьківщини.

Ключові слова: патріотичне виховання; військово-патріотичне виховання; зміст патріотичного виховання; курсанти; вищі військові навчальні заклади.

Jim. 8.

Borys Pantyukhov, Postgraduate Student of the General Pedagogy and Preschool Education Department Drohobych Ivan Franko State Pedagogical University

\section{CONTENT OF TRAINEES' PATRIOTIC EDUCATION IN HIGHER MILITARY EDUCATIONALINSTITUTIONS}

In this article the content of trainees' patriotic education in higher military educational institutions is generalized on the basis of the study of the legal framework. The author analyzes the basic tasks of educational work in higher military educational institutions; the importance of patriotic education of trainees is stated. The definition of "patriotic upbringing" of future officers is given. Despite different approaches to the definition of the concept "patriotic education", it is proved that the general for various definitions remains the position on its orientation towards the formation of patriotic consciousness, civic values, moral and patriotic qualities of the serviceman's personality. The main tasks of patriotic education of soldiers are also listed.

It is proved that the content of trainees' patriotic education in higher military educational institutions encompasses a system of knowledge, skills, norms and rules of conduct, the mastery of which ensures the formation of a socially active personality of a patriot citizen of Ukraine, who would be ready to defend the Motherland. The criteria for determining the content of the patriotic education of the trainees (compliance with the social order of the society, targeting on the main goal of patriotic education, reliance on universal human and national values and ideals, promotion of unity of education, development, psychological training and self-improvement of future officers, etc.) are listed. It is proved that the patriotic education of trainees in higher military educational institutions should be aimed at the instilling of love for the Motherland, loyalty to the military oath, moral and combat qualities, readiness for self-sacrifice in the name of the Motherland and its people, development of national dignity and pride for their homeland, love and respect for Ukrainian culture, language, art, historical past, state symbols, etc. The role of classroom and extra-curricular work of higher military educational institutions in the implementation of the content of patriotic education of trainees is shown. It is pointed out that there are shortcomings in the implementation of the content of patriotic education, which, in order to ensure the security of the country, should be overcome as quickly as possible.

Keywords: patriotic education; military patriotic upbringing; a content of patriotic education; trainees; the higher military educational institutions.

П остановка проблеми. Сучасний етап побудови професійної української армії, орієнтація на якісні параметри в їі подальшому розвитку висувають високі вимоги до професійної підготовки курсантів у військовонавчальних закладах. За останні десятиліття у вищих військових навчальних закладах відбулися прогресивні зміни, які справили суттєвий вплив на якість професійної підготовки офіцерського складу Збройних Сил: підвищився рівень вимог до абітурієнтів, поступово покращується навчальноматеріальна база освітнього процесу, зросла кількість кваліфікованих викладачів, в процес навчання курсантів впроваджуються сучасні педагогічні технології тощо.

Однак на сучасному етапі розвитку українського суспільства, пов' язаному із анексією Криму, окупацією частини східних територій Росією, увиразнилася проблема виховання військовослужбовців, зокрема патріотичного. 
Чітко стало видно промахи і помилки, допущені при підготовці офіцерських кадрів в минулі десятиліття. Тому одним 3 найважливіших завдань державної політики у сфері військовопедагогічної освіти є забезпечення високої якості професійної підготовки та виховання курсантів вищих військових навчальних закладів. Для реалізації цього завдання необхідно забезпечити сучаснуякість професійної освіти і виховання особистості курсанта в дусі високого почуття патріотизму; підвищити педагогічну роль всіх учасників освітнього процесу; посилити військово-професійну спрямованість підготовки курсантів тощо.

Аналіз останніх досліджень і публікацій. Загальні підходи до формування і розвитку особистості майбутніх офіцерів розкриті в працях В. Балашова, О. Барабанщикова, Б. Бархаєва, В. Вдовюка, В. Герасимова, П. Городова, Є. Долотова, А. Животюка, Д. Іщенка, Ю. Коровенка, О. Пометун, О. Сафіна, М. Феденка та інших педагогів і психологів.

Питання виховання, зокрема, патріотичного, військовослужбовців стали предметом досліджень В. Баранівського, В. Дзюби, Ю. Красильника, Л. Олійника та ін.

Проте актуальною залишається проблема дослідження змісту виховання патріотизму курсантів вищих військових навчальних закладів, що й стало метою статті.

Виклад основного матеріалу. Відповідно до Положення про особливості організації освітнього процесу у вищих військових навчальних закладах Міністерства оборони України та військових навчальних підрозділах вищих навчальних закладів України від 20.07.2015 р. [7] “виховна робота ... є невід'ємною частиною освітнього процесу і включає в себе організаційні, моральнопсихологічні, педагогічні, інформаційні, культурнопросвітницькі та військово-соціальні заходи, які проводяться 3 метою формування у курсантів (слухачів, студентів) морально-психологічних якостей, необхідних для військової служби, готовності виконувати завдання за будь-яких умов бойових дій на фоні високої емоційної напруженості”.

Серед основних завдань виховної роботи у вищих військових навчальних закладах МО України виділяються:

- виховання у курсантів (слухачів, студентів) глибокого почуття любові до України, ії народу, виховання в них бойових якостей, духовної та психологічної готовності зі зброєю в руках захищати Українську державу, формування якостей громадянина-патріота, особистої відповідальності за оборону і безпеку України;
- формування в особового складу ВВНЗ (ВНП ВН3) поваги до Конституції України та інших законів України, свідомого виконання вимог військової присяги і статутів Збройних Сил України, наказів Міністерства оборони України i начальника Генерального штабу Головнокомандувача Збройних Сил України;

- виховання у курсантів (слухачів, студентів) високих моральних і бойових якостей, психологічної стійкості на історичних традиціях українського народу, свідомого ставлення до виконання службових обов'язків, вірності традиціям і бойовому прапору; ефективне використання 3 цією метою військових ритуалів;

- виховання в курсантів (слухачів, студентів) якостей, необхідних майбутньому офіцеру, здатному грамотно навчати та виховувати підлеглих, зміцнювати військову дисципліну i організованість, підтримувати постійну бойову готовність, уміло згуртовувати військові колективи, працювати в умовах демократизації життя у військах (силах).

Положення про вищі військові навчальні заклади (ВВН3), затверджене наказом Міністерства оборони України від 27 травня 2015 р. конкретизує: до основних завдань ВВНЗ належить, зокрема, проведення військовопатріотичного виховання молоді [6].

Патріотичне виховання військовослужбовця ЗСУ виступає як організований, планомірний i цілеспрямований процес передачі особистості воїна національних цінностей і норм культури, спрямований на формування у нього національногромадянської самосвідомості, патріотичних переконань і поведінки, усвідомлення своїх вчинків i дії на благо народу і держави, готовності до захисту Вітчизни. Патріотизм виступає у вигляді патріотичних якостей, у кожній 3 яких поєднується пізнавальний, емоційний, вольовий, поведінковий компонент: патріотична самосвідомість, почуття патріотичного обов'язку і відповідальності, патріотична мужність, прихильність до національних та загальнолюдських цінностей, почуття національної гідності та гордості $[8,186]$.

У Концепції військово-патріотичного виховання у Збройних Силах України наведене таке визначення цього поняття: “Патріотичне виховання особового складу Збройних Сил України як складова загального виховного процесу є системною та цілеспрямованою діяльністю органів державної влади і місцевого самоврядування, органів військового управління, а також громадських організацій патріотичного спрямування 3 формування високої патріотичної свідомості, почуття вірності своїй Вітчизні, 
готовності до виконання конституційного України, високоморальних і патріотичних норм обов’ язку щодо ії захисту. Патріотичне виховання передбачає формування у громадян відповідного комплексу особистісних якостей, соціально значущих мотивів поведінки, гармонійного поєднання державних та особистих інтересів, подолання негативних процесів і явищ у духовній сфері суспільства та Збройних Сил України” [2].

Дещо інший підхід до визначення поняття “військово-патріотичне виховання” наведено у Концепції ідеологічної роботи у Збройних Силах України. Відповідно до названого документа, це процес цілеспрямованого, систематичного, організованого та планомірного впливу на свідомість і поведінку особового складу щодо формування патріотизму через виховання високих громадянських, моральних, психологічних, військово-професійних і фізичних якостей, необхідних для реалізації його інтелектуального та творчого потенціалу в інтересах всебічного розвитку суспільства і Збройних Сил України, забезпечення безумовної готовності до сумлінного виконання військового обов'язку та захисту Вітчизни [3].

Систему патріотичного виховання в збройних силах України, у т.ч. й на етапі підготовки майбутніх офіцерів, Я. Романовський визначає як “сукупність закономірно побудованих, динамічно пов'язаних компонентів: мети, завдань, змісту, засобів української етнопедагогіки, умов їх реалізації та взаємодії суб'єктів, які формують патріотизм у дусі природно-історичного розвитку української нації на кожному етапі цілеспрямованого, планомірного військовопедагогічного процесу” [8, 185].

Проте яким би не був підхід до означення поняття “патріотичне виховання", спільним для різних визначень залишається положення про його спрямованість на формування патріотичної свідомості, громадянських цінностей та моральнопатріотичних якостей особистості військовослужбовця.

Серед завдань патріотичного виховання військовослужбовців є такі:

- утвердження в свідомості особового складу Збройних Сил України любові до України та їі Збройних Сил, глибоких національних почуттів і патріотичних переконань, поваги до української мови, культури, історичного минулого, національних і військових традицій, гордості за належність до своєї держави, віри в іiї процвітання, згуртування особового складу навколо ідеї незалежності України;

- виховання в особового складу поваги до Конституції України і законів України, вимог Військової присяги та статутів Збройних Сил поведінки та діяльності, формування в них готовності до свідомого виконання своїх обов'язків і збройного захисту держави в цілому;

- формування в особового складу Збройних Сил України гордості та поваги до державних символів України (Державного Прапора України, Державного Герба України, Державного Гімну України), бойових прапорів військових частин (з'єднань) Збройних Сил України, військових ритуалів і військової символіки;

- поглиблення знань особового складу з історії України та її Збройних Сил (військових формувань українців), протидія викривленню та фальсифікації історії і турбота про їі об'єктивне та неупереджене висвітлення, збереження українських військових традицій і започаткування нових [2].

3 огляду на це варто звернути увагу на зміст патріотичного виховання майбутніх офіцерів, який $\epsilon$ тісно пов' язаним із завданнями патріотичного виховання. Насамперед зазначимо, що, на наше переконання, зміст патріотичного виховання курсантів ВВНЗ - це система знань, умінь, навичок, цінностей, норм і правил поведінки, оволодіння якими забезпечує формування суспільно активної особистості громадянинапатріота України, готового стати на захист Батьківщини.

Варто зазначити, що зміст виховання патріотизму курсантів ВВНЗ повинен:

- відповідати соціальному замовленню українського суспільства;

- спрямовуватися на реалізацію головної мети патріотичного виховання формування й розвитку патріотично налаштованої, всебічно і гармонійно розвиненої особистості майбутнього офіцера;

- спиратися на загальнолюдські та національні цінності та ідеали;

- сприяти єдності виховання, навчання, розвитку, психологічної підготовки та самовдосконалення майбутніх офіцерів [5, 164].

Відтак стає очевидним, що патріотичне виховання має спрямовуватися на виховання дієвої любові до Батьківщини, вірності військовій присязі, морально-бойових якостей, готовності до самопожертви в ім'я Вітчизни та її народу, розвиток національної гідності та гордості за свою Батьківщину, любові та поваги до української культури, мови, мистецтва, історичного минулого, державних символів України тощо.

Зміст патріотичного виховання майбутнього офіцера розкривається через вивчення національної історії, культури, народних традицій, звичаїв, обрядів, формування у курсантів ВВНЗ спроможності давати власну оцінку історичним 
подіям i фактам минулого i сучасного, патріотичного виховання, які задля безпеки країни забезпечення якнайповнішого задоволення національно-культурних інтересів, досягнення високих результатів у навчально-виховному процесі $[8,186]$.

Проте, як стверджує В. Барановський викладання історії у ВВНЗ від періоду здобуття незалежності і до другого десятиліття XXI ст. характеризується певними недоліками, адже “.... .історія України, їі військовий та українознавчий аспект недостатньо представлений до вивчення у вищих військових навчальних закладах держави. Скорочується кількість навчальних годин для вивчення історії України, історії військового мистецтва України, українознавства, української та світової культури у вищих військових навчальних закладах України. Досвід роботи зі слухачами, курсантами військових навчальних закладів свідчить про невисокий рівень їх світоглядної, культурологічної, українознавчої підготовки” $[1,38]$. На думку автора, “патріотичне виховання військових кадрів у ВНЗ має носити активний, творчий і наступальний характер. Патріотичний аспект має бути присутнім під час вивчення всіх навчальних дисциплін, під час гуманітарної (котра, відповідно до Концепції ідеологічної роботи в Збройних Силах України, заміняється воєнно-ідеологічною) підготовки, інформаційно-пропагандистських і культурнопросвітницьких заходів. Великі можливості щодо патріотичного виховання мають такі дисципліни як історія, філософія, українознавство, культура, педагогіка, психологія, виховна робота, моральнопсихологічне забезпечення життєдіяльності військ тощо” $[1,38]$.

Важливу роль у реалізації змісту патріотичного виховання відіграє позааудиторна робота: тематичні заходи 3 культурно-виховної та просвітницької роботи, участь у діяльності творчих колективів, шефська робота тощо. Проте, як засвідчило дослідження С. Левченка, “сучасний стан виховання у вищих військових закладах освіти характеризується безсистемністю, проведенням значної кількості різноманітних виховних заходів, які у своїй більшості не мають спільного методологічного підгрунтя і не об' єднані єдиною концепцією” $[4,7]$.

Висновок. Отже, патріотичне виховання курсантів вищих військових навчальних закладів на сьогодні $є$ важливою проблемою, яка потребує розв'язання як на теоретичному, так і на практичному рівні. Зміст виховної роботи у ВВНЗ регламентується низкою нормативно-правових документів. Проте аналіз практики діяльності цих закладів засвідчує недоліки у реалізації змісту

мають якнайшвидше бути подолані.

\section{ЛІТЕРАТУРА}

1. Барановський В.Ф. Національно-патріотичне виховання військової інтелігенції у вищих навчальних закладах України / В.Ф. Барановський // Військова освіта. - 2013. - № 1. - С. 34-40.

2. Концепція військово-патріотичного виховання у Збройних Силах України [Електронний ресурс]. - Режим доступу: http://www.mil.gov.ua/diyalnist/v\%D1 \%96jskovo-patr\%D1\%96otichna-robota/normativnopravova-baza-vijskovo-patriotichnogo-vihovannya/ nakaz-ministra-oboroni-ukraini-\%E2\%84\%96-295.html

3. Концепція ідеологічної роботи уЗбройних Силах України [Електронний ресурс]. - Режим доступу: http:/ / refs.in.ua/pro-zatverdjennya-polojennyapronarodoznavchu-svitlicyu-u-zbr.html?page $=44$.

4. Левченко С.М. Особистісно орієнтоване виховання майбутніх офіцерів у вищому військовому навчальному закладі: автореф. дис. на здобуття наук. ступеня канд. пед. наук: 13.00.04 - теорія та методика професійної освіти / С.М. Левченко. - Харків, 2004. $20 \mathrm{c}$.

5. Мотика С. Зміст виховання патріотизму учнівської молоді в умовах військового ліцею / С. Мотика, Л. Олійник// Військова освіта. - 2017. - № 2. - С. 161 169.

6. Положення про вищі військові навчальні заклади (ВВН3) [Електронний ресурс]. - Режим доступу : http:/ /zakon2.rada.gov.ua/laws/show/z0706-15

7. Положення про особливості організації освітнього процесу у вищих військових навчальних закладах Міністерства оборони України та військових навчальних підрозділах вищих навчальних закладів України [Електронний ресурс]. - Режим доступу: http:/ /zakon2.rada.gov.ua/laws/show/z1126-15

8. Романовський Я.Я. Історичні витоки формування патріотизму особистості у збройних силах України / Я.Я. Романовський // Держава та армія: [збірник наукових праць]/відповідальнийредактор Л. С. Дещинський. - Львів: Видавництво Національного університету “Львівська політехніка", 2008. - № 634. -С. 180-187.

\section{REFERENCES}

1. Baranovskyi, V.F. (2013). Natsionalno-patriotychne vykhovannia viiskovoi intelihentsii u vyshchykh navchalnykh zakladakh Ukrainy [National-patriotic education of military intelligentsia in higher educational institutions of Ukraine]. Viiskova osvita, no. 1, pp. 34-40. [in Ukrainian].

2. Kontseptsiia viiskovo-patriotychnoho vykhovannia u Zbroinykh Sylakh Ukrainy [Concept of military-patriotic education in the Armed Forces of Ukraine]. Available at: http://www.mil.gov.ua/diyalnist/v\%D1\%96jskovopatr\%D1\%96otichna-robota/normativno-pravova-bazavijskovo-patriotichnogo-vihovannya/nakaz-ministraoboroni-ukraini-\%E2\%84\%96-295.html [in Ukrainian].

3. Kontseptsiia ideolohichnoi roboty u Zbroinykh Sylakh Ukrainy [Concept of ideological work in the Armed 


\section{ФОРМУВАННЯ У ПІДЛТТКІВ ІНТЕРЕСУ ДОЗАНЯТЬ ТУРИЗМОМ В УМОВАХ ЛІТНЬОГО ОЗДОРОВЧОГО ТАБОРУ: ПОСТАНОВКА ПРОБЛЕМИ}

Forces of Ukraine]. Available at: refs.in.ua/prozatverdjennya-polojennya-pronarodoznavchu-svitlicyuu-zbr.html?page $=44$. [in Ukrainian].

4. Levchenko, S.M. (2004). Osobystisno oriientovane vykhovannia maibutnikh ofitseriv u vyshchomu viiskovomu navchalnomu zakladi [Personally oriented upbringing of future officers in a higher military educational institution]. Extended abstract of candidate's thesis. Kharkiv, 20 p. [in Ukrainian].

5. Motyka, S. \& Oliinyk, L. (2017). Zmist vykhovannia patriotyzmu uchnivskoi molodi $v$ umovakh viiskovoho litseiu [The content of upbringing patriotism of student youth in conditions of military lyceum]. Viiskova osvita, no. 2, pp. $161-169$. [in Ukrainian].

6. Polozhennia pro vyshchi viiskovi navchalni zaklady (VVNZ) [Regulations on Higher Military
Educational Institutions (HMEI)]. Available at: http:// zakon2.rada.gov.ua/laws/show/z0706-15 [in Ukrainian].

7. Polozhennia pro osoblyvosti orhanizatsii osvitnoho protsesu u vyshchykh viiskovykh navchalnykh zakladakh Ministerstva oborony Ukrainy ta viiskovykh navchalnykh pidrozdilakh vyshchykh navchalnykh zakladiv Ukrainy [Provisions on the peculiarities of the organization of educational process in higher military educational institutions of the Ministry of Defense of Ukraine and military training units of higher educational institutions of Ukraine]. Available at: http:// zakon2.rada.gov.ua/laws/show/z1 126-15 [in Ukrainian].

8. Romanovskyi, Ya.Ia. (2008). Istorychni vytoky formuvannia patriotyzmu osobystosti u zbroinykh sylakh Ukrainy [Historical origins of personality patriotism formation in the armed forces of Ukraine]. Derzhava ta armiia, Lviv, no. 634, pp. 180 - 187. [in Ukrainian].

Стаття надійшла до редакції 18.05.2018

УДК $373.5-053.6: 796.5$

DOI:

Христина Щербанік, аспірант кафедри загальної педагогіки та дошкільної освіти Дрогобицького державного педагогічного університету імені Івана Франка

\section{ФОРМУВАННЯ У ПІДЛІТКІВ ІНТЕРЕСУ ДО ЗАНЯТЬ ТУРИЗМОМ В УМОВАХ ЛІТНЬОГО ОЗДОРОВЧОГО ТАБОРУ: ПОСТАНОВКА ПРОБЛЕМИ}

У статті виявлено шляхи $і$ засоби формування інтересу в підлітків до занять туризмом в умовах літнього оздоровчого табору; з'ясовано психолого-педагогічні аспекти проблеми; обтрунтовано методологічні засади проиесу; відтворено алгоритм його виникнення та розвитку; визначено дидактичне забезпечення у поєднанні спортивної, оздоровчої, рекреаційної, краєзнавчої діяльності з метою пізнання, розвитку та виховання.

Ключові слова: підлітки; літній оздоровчий табір; туризм; формування інтересу.

Jim. 15.

Khrystyna Shcherbanik, Postgraduate Student of the General Pedagogy and Preschool Education Department Drohobych Ivan Franko State Pedagogical University

\section{THE ADOLESCENTS' FORMATION OF INTEREST IN PURSUING TOURISM IN THE CONTEXT OF A SUMMER HEALTH CAMP: THE STATEMENT OF THE PROBLEM}

The article reveals the ways and means of psychological and pedagogical aspects of the formation of interest of teenagers in pursuing tourism activities in the conditions of a summer health camp; the methodological principles of the process are substantiated, the algorithm of its origin and development is reproduced; the didactic support in a combination of sports, recreational, local lore activities for the purpose of knowledge, development and upbringing is defined. It was found out that the reasons for the decline of the interest of adolescents in tourism activities is the lack of proper motivation for them, which should be based on actualization of the principles of a personally oriented approach, valeological culture of personality and social competence.

The formation of the adolescents' interest in pursuing tourism in the context of a summer health camp involves the consideration of a number of factors in this process, in particular: the psycho-physiological features of adolescence, the dialectic of the emergence and the development of interest in pursuing tourism through informed needs, as well as the guides of philosophy and pedagogy of holidays, tourism pedagogy; the creation of the pedagogical conditions of a summer recreation camp for rest and recreation in accordance with the requirements of the normative and legal documents, regulating work outside institutions of this type; the contradictory relationship of personally-individual ("I") and group ("WE") motives, etc. The expected result in the process of formation of interest in tourism activities in the conditions of a summer health camp we get in the unity of knowledge of adolescents (the possibilities of acknowledgement of ourselves and the world by means of tourism), cognitive, sports and recreational tourism activity and satisfaction from its results.

Keywords: adolescents; a summer health camp; tourism; the formation of interest.

П

остановка проблеми. Формування у підлітків інтересу до занять туризмом в умовах літнього оздоровчого табору

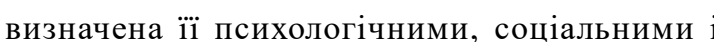
педагогічними аспектами, оскільки цей процес може відбуватися у виховному просторі сім’ї, 